\title{
Better-off Women Boosting Groundnut Business in Ghana
}

\subsection{More Groundnut Means Shelling Is a Business}

Groundnut was one of the biggest breeding programs in Ghana in the mid-nineties, but the production declined because of many factors including the rosette disease and the fact that there was no dedicated breeder of groundnut for over 10 years. According to Dr. Roger Kanton, Deputy Director of CSIR-SARI (Council for Scientific and Industrial Research - Savanna Agricultural Research Institute), it was then, in 2015, with the support of the Tropical Legumes Projects that the groundnut breeding program was reinitiated. "Only a few local germplasms were available,” adds Dr. Richard Oteng-Frimpong, a young groundnut breeder, who came along with the support of the Tropical Legumes projects to start again the breeding program in 2015.

Groundnut production and processing in Nyankpala, Northern Ghana, is now seen as a business. Umar Jibril, a fabricator of groundnut shellers, narrates, "In 2006, we could barely fabricate one or two groundnut shellers in the year. Now we fabricate up to 4 groundnut shellers per month; the demand is very high to a point that clients must place an order well in advance. Our clients used to be the villagers but nowadays our clientele is made of small and medium enterprises."

Since 2015 and through the Tropical Legumes projects, SARI collected more than 300 new materials mainly from ICRISAT. Up to 109 breeding lines were developed and with the assistance of the projects new irrigation facilities were developed and two advanced generations were created each year. Main traits including resistance to foliar diseases, drought tolerance, oleate, early maturity, and oil content were investigated, tested, and evaluated with farmers. As a result, a total of five varieties were promoted and 3 tons and 8.4 tons of foundation seed were made available in 2015 and 2016, respectively. About 42 tons of certified seed were produced in 2016. According to the Deputy Director of CSIR-SARI, three new varieties are in the final stage to be released. "The material release will bring SARI and Ghana back to groundnut breeding,” explains Dr. Kanton.

The existing old varieties had a yield potential of 1.8 tons/ha while the new materials have a yield advantage over the existing varieties between 10 and 30\%. Before 
the Tropical Legumes projects, the amount of breeder seed produced per year was less than 0.2 ton. With the support of the projects, 2 tons were produced in 2015 and 6 tons in 2016.

"The increase in breeder seed production means that seed companies have better access to breeder seed to produce foundation seed; it also means that out-growers are producing certified seed and that farmers can enhance their community seed production,” says Mr. El Hadj Abdul Razak, Director of Heritage Seed Company. Since 2016, the company was linked to 300 nucleus farmers that he supplies with foundation seeds for the production of certified seed. The company produces on demand and supply to many partners including NGOs. "The market is very interested in new varieties and for 3 years now, we have been having a problem in meeting the demand," he says.

From zero, 3 tons and 8.4 tons of foundation seed were produced in 2015 and 2016 respectively. A total of 42 tons of certified and Quality Declared Seed (QDS) were produced in 2016, says Razak.

This success is the results of several trainings organized on good agronomic practices among groundnut producers and key players along the value chain within multi-stakeholder platforms (MSPs) established under TL Projects. Such trainings focused on groundnut seed production and agronomy, weed management in seed fields, pest and diseases management, post-harvest handling, establishing community-based seed systems and seed certification. Also, trainings were provided on maintaining a viable seed business targeting groundnut seed producers, out-growers, and inputs dealers. From 2015 to 2017, more than 8000 farmers were reached with improved varieties.

With more breeder seed, foundation seed, certified seed, and Quality Declared Seed (community seed systems), not only farmers, out-growers, and seed companies could increase their production and yield but a range of new businesses also appeared in the value chain, including shellers that would speed up the processing. Mr. Umar Jibril (Fig. 8.1) is a sheller maker in Nyankpala, Northern Ghana. He has noticed a boom in the demand for groundnut sheller during the past 2 years. "In 2006, we could fabricate barely one or two shellers in the year, but we can now fabricate up to 4 shellers per month as the demand is very high to a point that one must place an order well in advance," says Jibril. "Initially, our clients used to be the villagers, but with time our clientele has diversified." The fabricator who used to work alone with his uncle in a small garage is now the owner of an enterprise of ten employees.

One sheller can be sold up to 3600 Ghana Cedi (1 USD equals 4.5 Ghana Cedi during that period), and one machine can shell up to $4000 \mathrm{~kg} /$ day. Each bag of $40 \mathrm{~kg}$ is shelled at a cost of 3 Ghana Cedi. "People had seen groundnut production and processing as a business," says Jibril. "Now we have many entrepreneurs who buy our shellers to make them work in village". Figure 8.2 shows active women operating at a groundnut shelling station.

With the increase in groundnut production, Mr. Seidu Bushira and his wife Seidu Andani (Fig. 8.3) have initiated a groundnut shelling business near Tamale city. The 


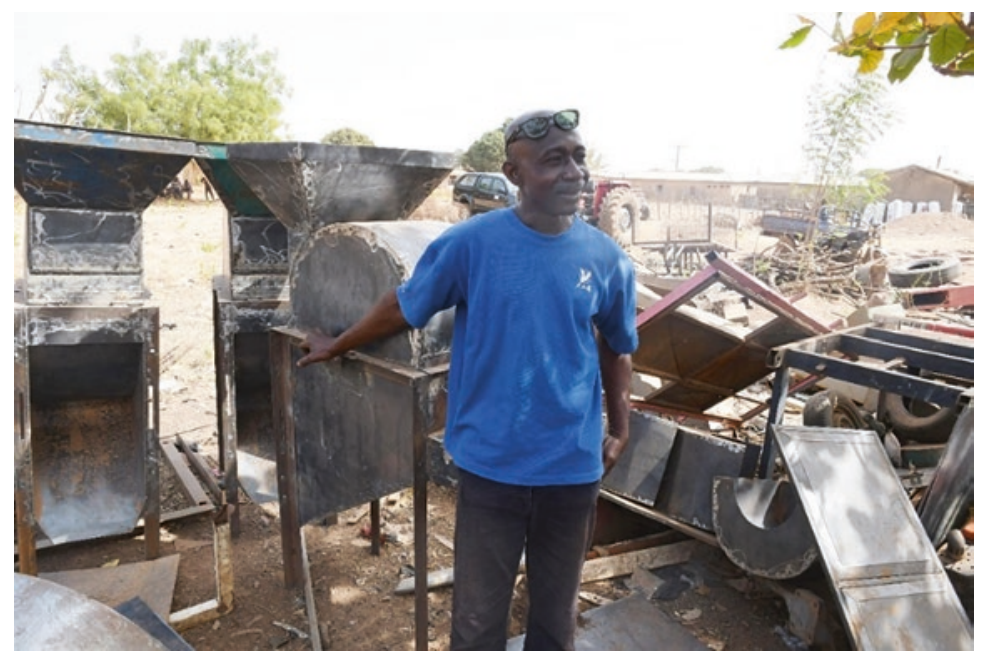

Fig. 8.1 Mr. Umar Jibril in front of two fabricated shellers, Ghana (Photo: Diama A)
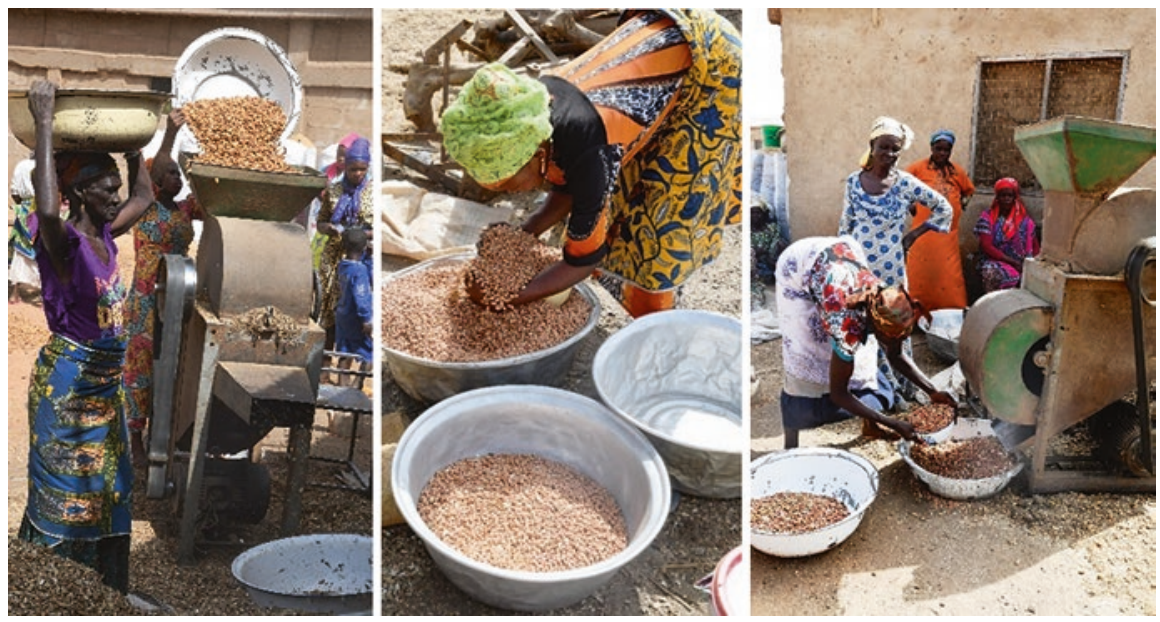

Fig. 8.2 On left: women operating the groundnut sheller. On right, a woman prepares shelled groundnut for the market, Ghana (Photo: Diama A)

couple which employs about 20 daily workers has two groundnut shellers. "Before the boom in the groundnut production, we use to shell only $400 \mathrm{~kg}$ per day, now we can process up to $600 \mathrm{~kg}$," said Bushira. Groundnut producer like Mr. Abdul Majeed can now shell their groundnut as fast as possible to proceed to the market. Mr. Abdul Majeed (Fig. 8.4), a diploma holder in Business studies, has taken up the existing market opportunity to farm 4 acres on which he harvested 2.5 tons. With money earned, the young student plans to pursue a higher national diploma in Business studies with management option. 


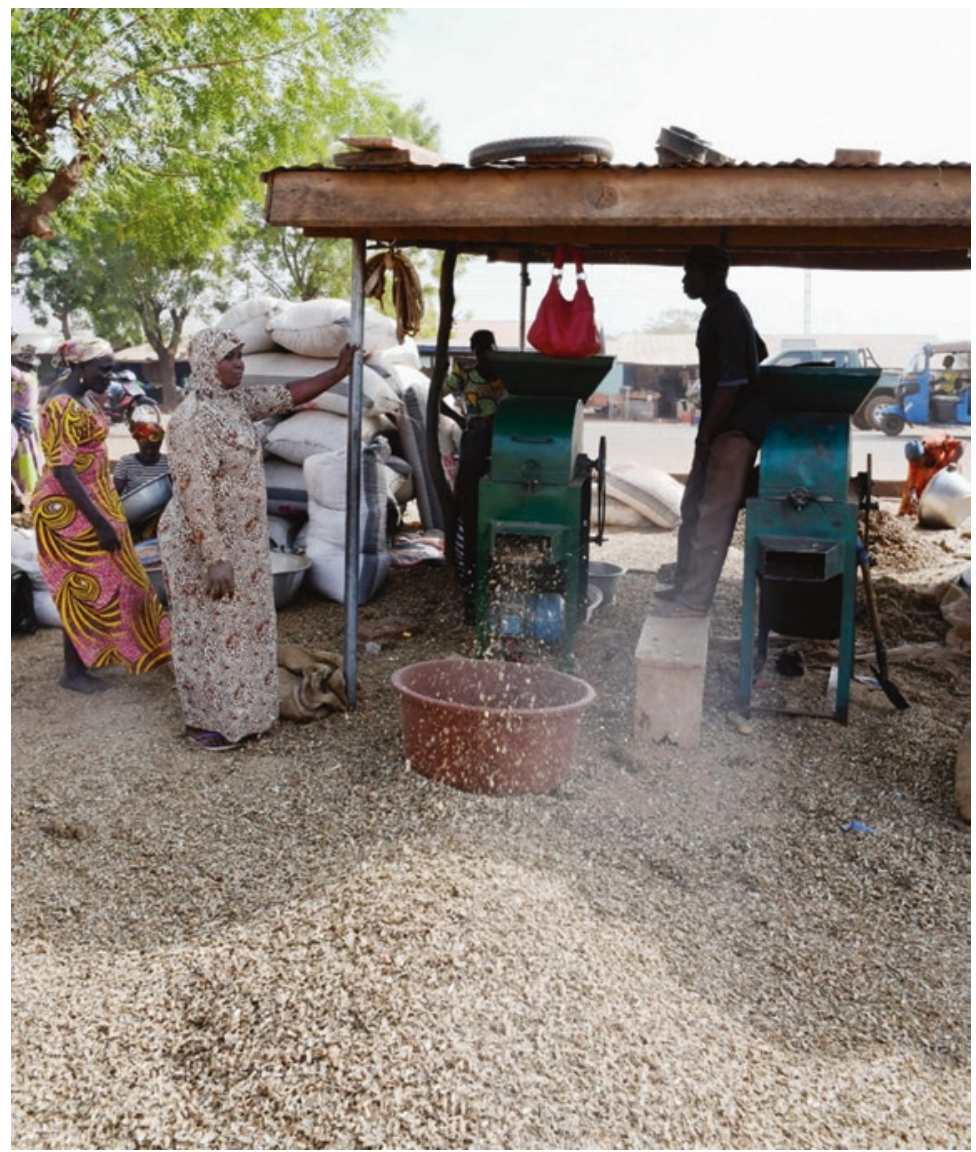

Fig. 8.3 Mr. Seidu Bushira (first right) and his wife Seidu Andani (second left) (Photo: Diama A)

Women in the communities are heavily involved in groundnut business (Fig. 8.5)

\subsection{Village Savings and Loans Association (VSLA) Boosting Groundnut Production Among Small Holder Farmers in Northern Ghana}

Empowering small holder farmers to be financially independent is very crucial to ensuring a constant crop production system. Access to credit in the form of cash and inputs for production has always been a major constraint bedeviling the crop production sector. Interest rates charged on credit accessed from financial institutions tend to be often high, thus making farmers reluctant in accessing them. Another major challenge farmer's face in accessing credit is the repayment terms of credits. Financial institutions have often had hectic time dealing with farmers when it comes to recovery of the loan farmer received for 


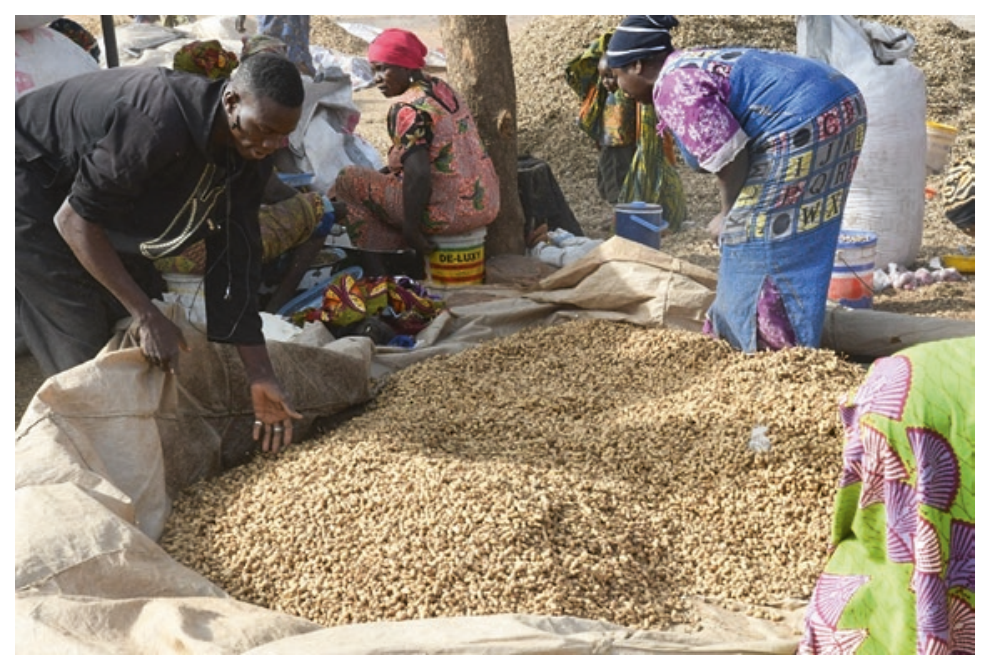

Fig. 8.4 First on left, Mr. Abdul Majeed (a student and groundnut producer who has brought his produce (2.5 tons) for shelling (Photo: Diama A)
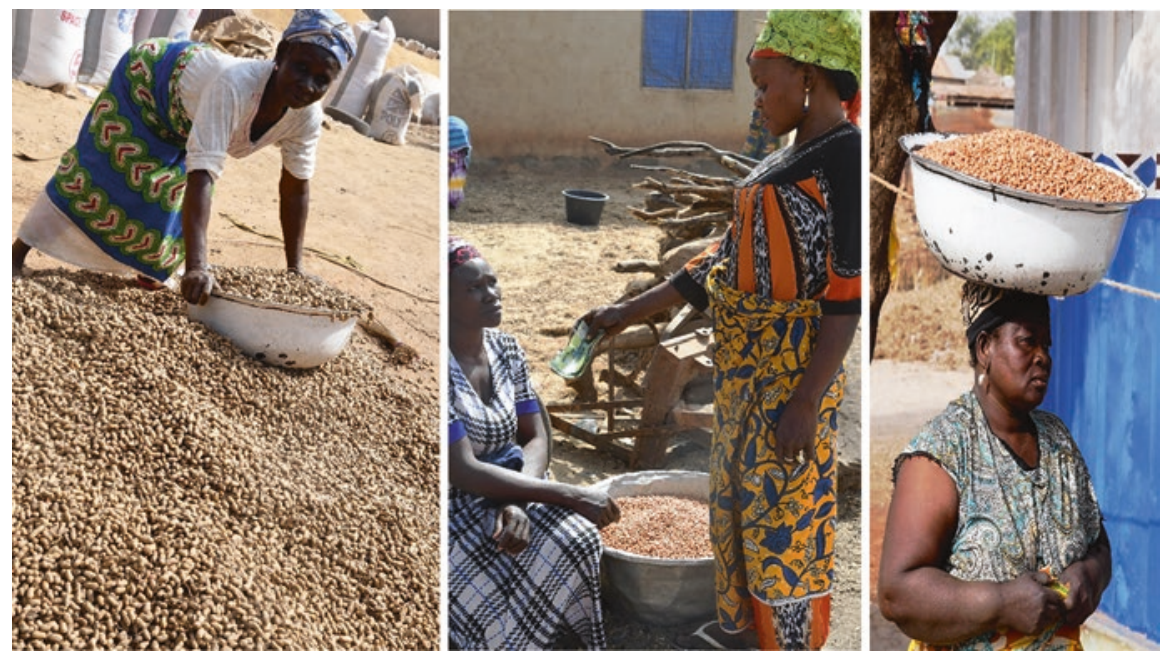

Fig. 8.5 Groundnut businesswomen in communities

crop production. This is because most of the farmers are not able to repay back their loans.

Several organizations have often rolled out programs aimed at reducing the plight farmers go through in accessing credit facilities by providing inputs while farmers repay back with grain, but this has yielded very little results. This is because farmers refuse to repay credit incentives packages given to them, making it difficult for them to roll out their interventions to other communities or individuals who need assistance. 
In Northern Ghana, TL project has partnered with SEND-Ghana (Social Enterprise Development), an NGO to put in place a Village Savings and Loan Association (VSLA) in five districts of Ghana (three in northern regions, one in Upper West Region and another one in Upper East region). Since then, VSLA has been used as a platform to help groups raise funds to support activities that require financial assistance (Figs. 8.6-8.8). "This VSLA is a self-help initiative, where group members come together to raise funds through weekly or monthly contributions within a given period of time," explains Mr. Desmond Adogoba, Gender and Social Scientist, SARI.

\subsubsection{Formation of Village Savings and Loans Association (VSLA)}

The implementation of the concept was derived from strategies developed from a gender workshop organized by the TL projects, aimed at bridging production gap between smallholder male and female farmers. "The objective of this initiative is to give members the chance to save money that will be used for groundnut seed
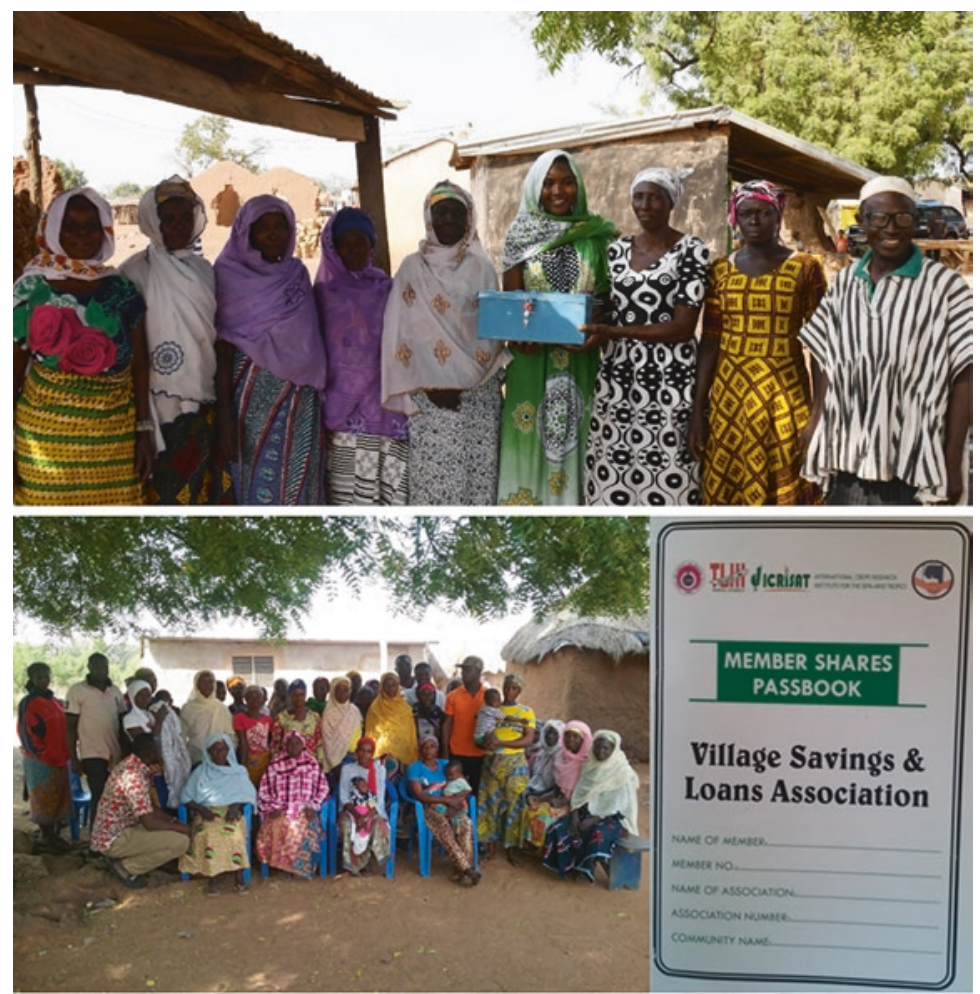

Fig. 8.6 TL improves women access to credit and strengthens their participation in groundnut seed systems, Ghana (Photo: Diama A) 

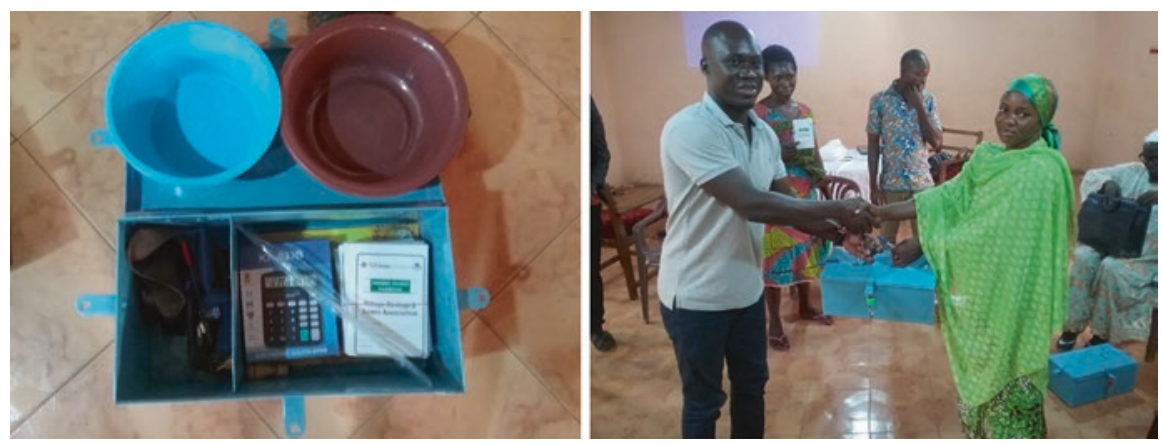

Fig. 8.7 On left: The complete VSLA kit is composed of a calculator, a membership card, a metal box for keeping the savings, and two plastic boxes used to collect money during weekend meetings. On right: Presentation of VSLA kits to community volunteers (from left to right Mr. Desmond Adogoba (Gender and Social Scientist, SARI) presenting a VSLA box to a community volunteer.)

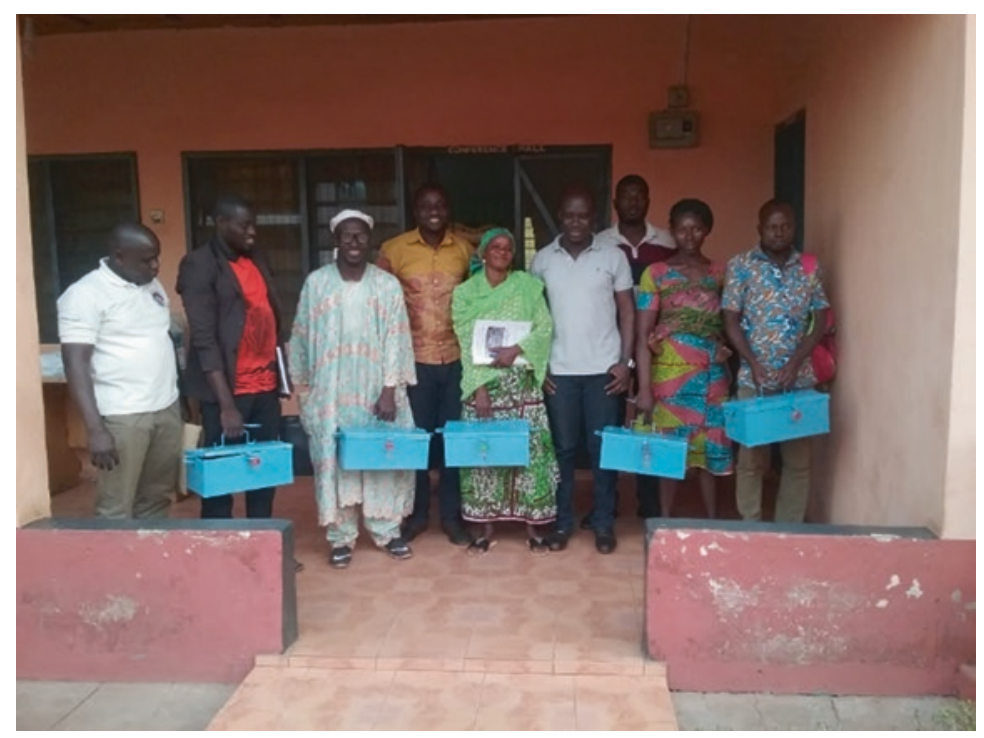

Fig. 8.8 Group picture with VSLA community volunteers in January 2018 (third from left is Mr. Sardi Linus Handua, Secretary of the Gbimsi "Tilanngum" VSLA, Ghana (Photo: Diama A)

production in their respective communities as well as support other households in on-farm activities which would have required borrowing money from external sources to execute them. This initiative helps equip members to be financially independent and strengthen the groundnut seed production system at the community level," said Mr. Desmond Adogoba. "We are not only empowering women, we are strengthening and engaging them into the seed systems," he adds. 
The VSLA initiative is piloted under the projects in five communities across five districts in northern Ghana (the Wantugu community in the Tolon District, the Salankpang community in the Mion District, and the Gbimsi community of the West Mamprusi District) and each VSLA has 150 members across the five pilot communities.

Mrs. Patience Ayamba is the program coordinator for the SEND-Ghana Livelihood and Food Security program. She is based in the Salaga Office of SENDGhana, where she coordinates activities of the SEND-Ghana livelihoods program across northern Ghana. She said that partnering with SARI through TL projects has helped them in expanding their gender training activities and VSLA into Northern Ghana. She expects that this partnership will lead into taking these communities to the Gender Family Model Concept where a husband, wife, and children are included. As she says, "VSLA is just a part of the Gender Family Model where both men and women get to understand their roles in the families. We have seen women taking more participation in decision making at the family level and even at the community level; with more women taking leadership role. With this model, we have seen men who are willing to support their wives in household burden, paying more attention to children's health needs and women have seen their views more respected by their husbands. We have seen these things happenings with SEND-Ghana fostering project. With lot of hard work, we expect to get the same good impact from five communities in which we are collaborating with the SARI and TL projects."

The formation of VSLA will be used to address three major problems identified during a study conducted to determine gender productivity gaps among small holder farmers across northern Ghana under the TL projects. These are access to credit, access to improved variety seeds, and access to fertile lands.

\subsubsection{Training of VSLA Community Volunteers}

One community volunteer was selected from each of the five VSLAs for a special training on the management plan of the VSLA in Tamale, the Northern Regional capital. The trained volunteer then gave a step-down training to other members of the group. The community volunteers were given an intensive one-day training at the conference hall of the Christian Council Guest house in Tamale on the 17th of January 2018. They were taken through the concepts of the VSLA by Mr. Samuel Wangul, a facilitator from SEND-Ghana.

Participants were also given training on the drafting of the VSLA constitution and how to keep records on savings passbooks. A practical session was also conducted to assess participants' understanding of the concept and to identify challenges they will encounter during record keeping. They were also taken through the process of issuing loans to group members, how to calculate interest rates as well as recover loans from members. The team then presented a set of VSLA kit to each group to enable them to start the savings process in their respective communities.

Mrs. Dachia Midana and Hajia Poanaba Sumani, leaders in the Gbimsi "Tilanngum" VSLA, say that savings will be used to expand their farmland "We 
want to use this VSLA savings to cultivate 60 acres of groundnut in 2018 cropping season." The Gbimsi "Tilanngum" VSLA, located in the Gbimsi community of the West Mamprusi District of Northern Region, has a total membership of 30 volunteers who are all female. The VSLA has eight elected executives to manage financial affairs of the group and meets once a week to make weekly contributions. The group has engaged the service of a male secretary who helps them in their day-to-day record keeping, since all members can neither read nor write. The group has also been subdivided into five "Solidarity groups" with a membership of six per group for the community groundnut seed production.

In Gbimsi "Tilanngum," as all other communities where VSLA were created, a training process to also sensitize chiefs and land owners at the community level on the need to release fertile arable lands to female farmers was largely agreed upon. "This has given hope that women will have better access to arable land for groundnut and other crops cultivation," says Mr. Sardi Linus Handua, the male Secretary of the VSLA Gbimsi "Tilanngum."

The VSLA are also giving a relief to members who can contribute better the school fees for their children. According to Handua, the average school fees paid yearly for primary student is 1000 Ghana Cedi (about 200 US Dollars). "Ijoined the VSLA because I can save money, get credit for income generating activities that will enable me to pay school fees for my 4 children who are all in senior high school," says Ms. Dachia Midana. "Moreover, I can get money to prefinance my children schoolfees."

\subsection{Cutting Down the Breeding Cycle and Revamping the Groundnut Seed Systems}

From $40 \mathrm{~kg}$ to 6 tons of breeder seed, 8 tons of foundation seed, and 37 tons of certified seed in 2017, Ghana is back to groundnut production

The fact that we can even mention an existing groundnut program in Ghana is in itself a success. Before the Tropical Legumes projects, there were no groundnut breeding program in Ghana,-Dr. Richard Oteng-Frimpong reported.

Groundnut is the most important grain legumes in Ghana and CSIR-SARI is mandated to carry out the research on groundnut in Northern Ghana. "Up to 2006, there were no funding to support the research on this crop, until Tropical Legumes started and were road- on in 2012," says Dr. Richard Oteng-Frimpong (Fig. 8.9), the groundnut breeder and seed systems scientist at SAR Ghana.

Richard first joined the projects with his research center in 2012 to start a groundnut program with $40 \mathrm{~kg}$ of available breeder seed, along with 57 new breeding lines obtained with ICRISAT as part of the Tropical Legumes projects. "In the same year, we were able to conduct single location trial," says Richard. However, between 2013 and 2015, Richard says the program slowed down because there were no groundnut dedicated breeder. 

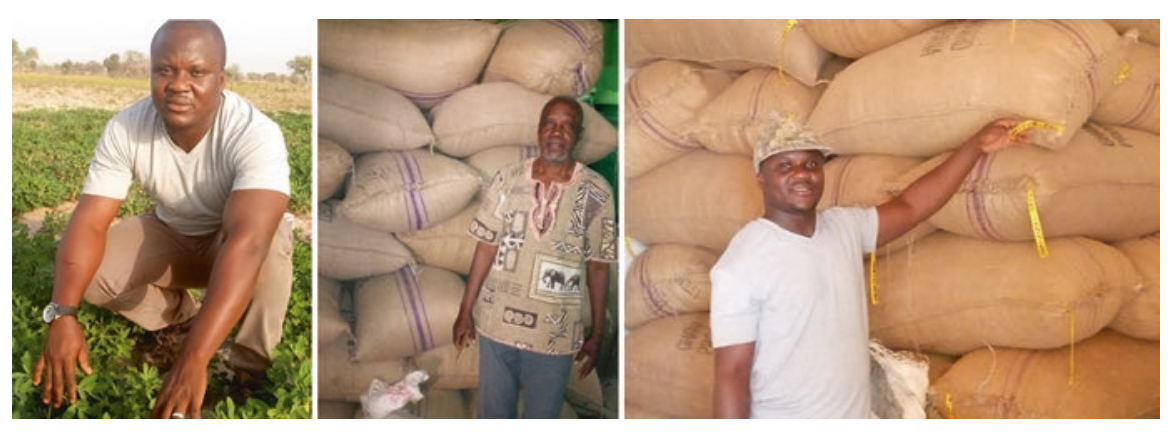

Fig. 8.9 From left to right: Dr. Richard Oteng-Frimpong, groundnut breeder, and Mr. El Hadj Abdul Razak, Director General of Heritage Seed Company Ltd. (Photo: Diama A)

In 2015, when Richard resumed work in SARI as a breeder and with the support of the Tropical Legumes, the Ghana groundnut breeding program eventually started again from scratch. "We collected 300 new germplasm from the ICRISAT and since, we have been able to develop 109 new breeding lines out of them. Now we have our own breeding nursery and crossing program with 16 new crosses developed in 2017. Our target is to reach up to 20 new crosses per year."

This breakthrough is also linked with increased on-farm participatory varietal selection (PVS), where up to 44 PVS were conducted in 2016 by an institution where groundnut breeding was nonexistent. Furthermore, the program has established a groundnut inspection plot to speed up the release of new varieties. "This plot is established for inspection by the groundnut release committee. If it goes well, we are expecting to release 3 new varieties in 2018. Sensorial evaluation and nutritional varieties have also been completed as well and with regard to all aspects, the varietal release committee will make a decision," Oteng-Frimpong explains.

Tropical Legumes II and Tropical Legumes III projects have revived groundnut breeding program in Ghana, confirms Dr. Roger Kanton, Deputy Director of CSIR-SARI. We started from zero and now we have a fully fledged groundnut breeding program. We have breeding materials developed inhouse from our own crosses. With the new germplasm obtained from ICRISAT and other partners within the project, we were capacitated to undertake more experiments on yearly basis, and by so doing, we are cutting down the breeding cycle, Kanton adds.

In 2016, SARI groundnut breeding program successfully produced 6 tons of breeder seed, 8 tons of foundation seed, and 37 tons of certified seed. "No one will say that SARI groundnut program is dead as they use to say. Tropical Legumes and the USAID funded groundnut upscaling projects came to revive groundnut program in Ghana. Without any doubt, we would not have reached to this extent without the support of both projects," Oteng-Frimpong adds.

Partnerships were very instrumental in the success of the new groundnut breeding program. With the additonal support of the USAID-funded groundnut 
upscaling project, the TL project in Ghana extended and targeted more communities using participatory varietal demonstration plots and field days. "There were not much varietal demonstrations before TL projects. The existing varieties were kept without promotion of any kind and only very few farmers knew about them. With the TL projects, 57 PVS were conducted in 2016 and up to 65 PVS in 2017."

Also, we have acquired car to facilitate mobility. "Due to our high mobility, we have moved from one multi-locational trial up to six multi-locational trials in a year. The multi-locational trials conducted in the Guinea Savanna only have been extended into the Soudan Savanna."

With new irrigation facilities which allow to phenotype for drought tolerance traits in the existing germplasm, the groundnut breeding program can plan bigger for projects. "We have been able to acquire a SPAD chlorophyll meter, a portable leaf area meter, a data longest that allow us to set up our own weather portable station and enable us to measure soil moisture level and also the environmental condition. All these facilities are helping us to develop drought tolerance materials for our target region. With the irrigation system functioning, we can have two cropping seasons in a year, we are able to produce early generation seed also on these facilities."

Since 2015, the Tropical Legumes projects and the USAID-funded groundnut upscaling project have reached over eight thousand (8000) farmers (including 45\% of women) and this is expected to continue increasing during the coming years. According to Dr. Oteng-Frimpong, this is because they have strong basis foundation to build upon. The TL projects which covered only three districts in 2015 is now targeting 30 districts in Ghana.

\subsection{A Very Innovative Way of Making Foundation Seed Available to the Seed Producers}

The increase in breeder seed production has improved the access of seed companies to foundation seed and out-growers are producing more certified seed. "Four years ago, there were no breeder seed of groundnut available; we were all relying on one popular variety called Chinese,” recalled Mr. El Hadj Abdul Razak (Fig. 8.10), Director General of Heritage Seed Company based in Tamale, Northern Ghana. "In 2013, I heard of an improved variety but could not get access to it." In 2017, the seed company produced about 60 metric tons of the improved groundnut Samnut 22 (shelled). The customers of the seed company include a network of 300 seed outgrowers and individual farmers to whom small seed pack of $20 \mathrm{~kg}$ of the improved variety Samnut 22 have been distributed to.

The project found a very innovative way of getting foundation seed into the seed value chain. Breeder seed problem is of the past and as a seed company, we have a big market for improved varieties of groundnut and cowpea," says Razak. "Many farmers were equipped 


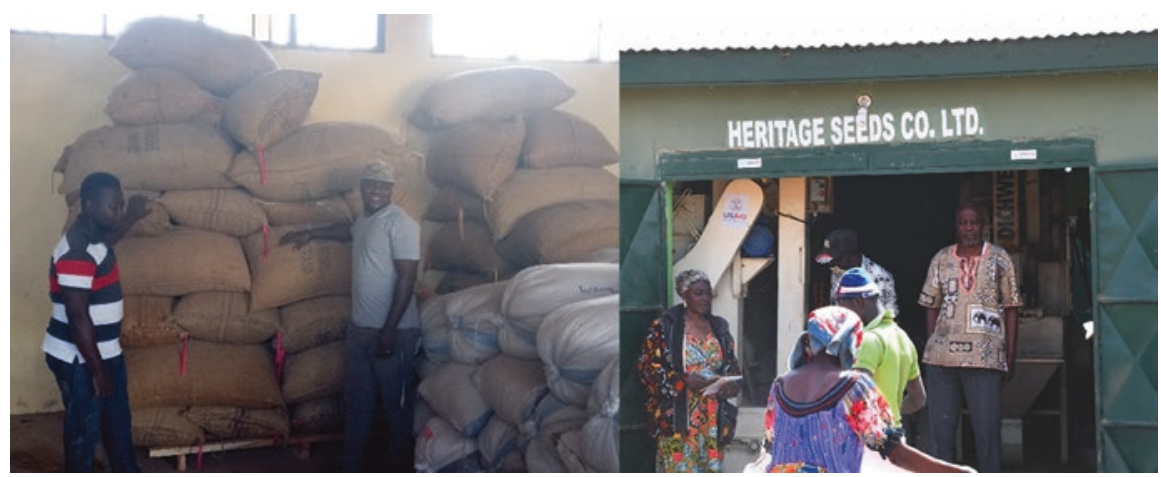

Fig. 8.10 Left: Mr. Rachid, Research technician, and Dr. Richard Oteng-Frimpong, groundnut breeder, are happy to show breeder seed ready to be distributed to seed companies. Right: Mr. El Hadj Abdul Razak, Director General of Heritage Seed Company Ltd. (Photo: Diama A)

with knowledge and skills in cowpea and groundnut production, and connected to our company with production contracts so that they can produced and injected enough certified seed. Before then, our company was very limited to only two communities. Now we work with seed out-growers in 8 communities.

Mr. Fuseini Zaanyeya (Fig. 8.11) is member of one nucleus farmers' group involved with Heritage Seed Company in production of certified seed. He joined the network of the nucleus farmers of Heritage Seed in Gberimani-Tibogu community, Tolon District, Northern Ghana. "Someone told me that they have a group supported by a seed company. The fellow introduced me to the Director General of Heritage Seed Company; that's how I came into cowpea production. He gave me $10 \mathrm{~kg}$ of cowpea seed which I first planted on 1 Acre and harvested about 0.5 tons in 2015. The following year, four other youth in the village embarked on cowpea production where we were all given 50kg by the same seed company. In 2017, we were 25 farmers using a total of $250 \mathrm{~kg}$ of the improved varieties provided by the seed company."

Before then, like several other youth from his community, Mr. Fuseini Zaanyeya used to travel to the capital city of Accra in Southern Ghana where he sought in vain for greener pastures to better his standard of living. His dream to secure a tractor for expanding his field operations for increased productivity and better living standard came true when he returned to his community and settled on cowpea production as a business. He is currently the chairman of a farmer group engaged in cowpea seed business under Heritage Seed Company within the Gberimani-Tibogu community of Northern Ghana. Mr. Fuseini Zaanyeya says he can now afford to pay school fees and hospital bills for his children.

With his earnings, Mr. Fuseini Zaanyeya was able to purchase a new tractor which he now uses to render service to fellow farmers in the village. More recently he bought a motorbike which he says will enhance his mobility from his village to the district capital city (Tolon) where he has acquired a piece of land. He plans to construct a new house for renting and get money and settle a house for his two children in preparation for them getting into senior school. 

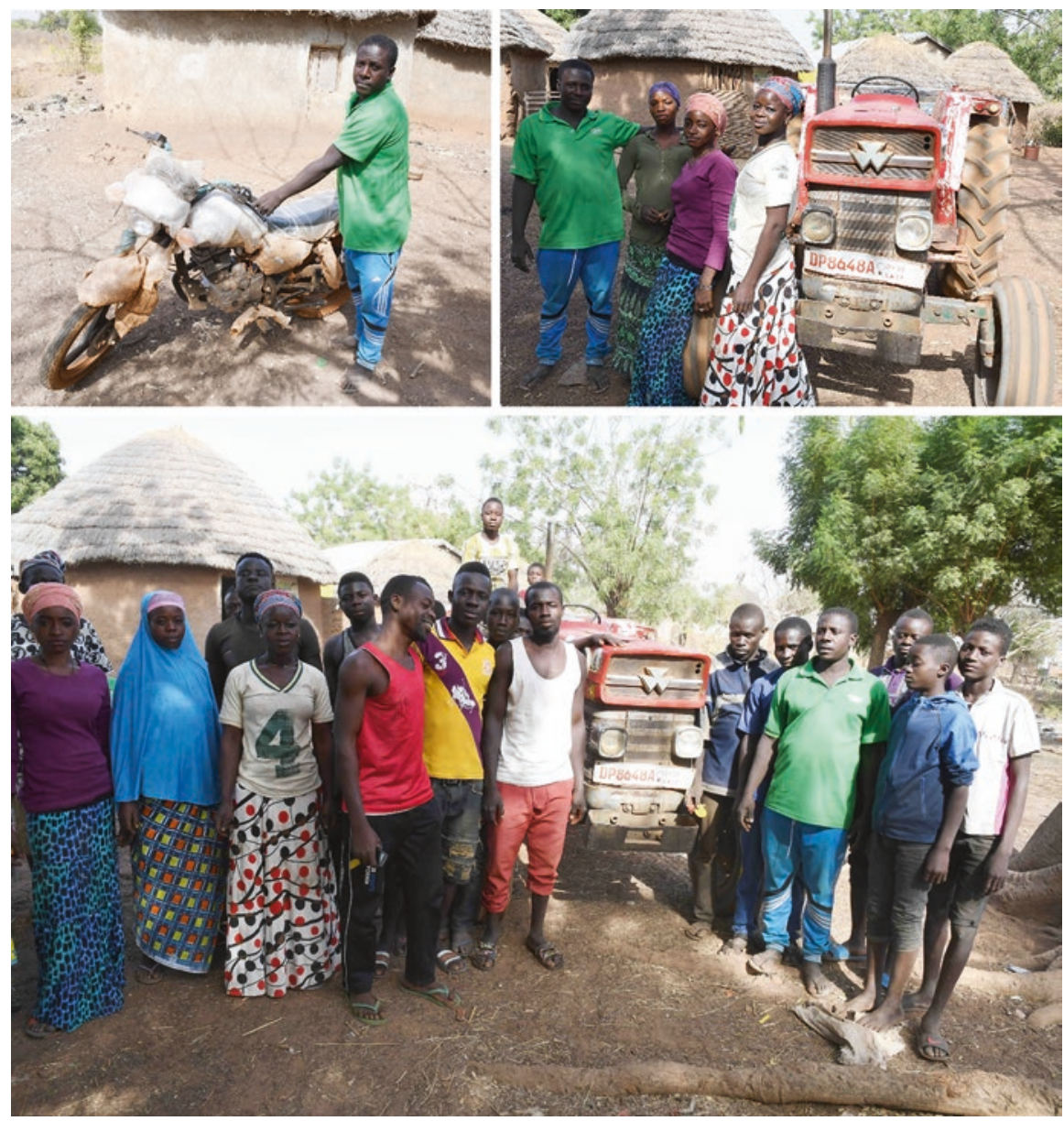

Fig. 8.11. First from left: Mr. Fuseini Zaanyeya with his new motorbike. First from right: Mr. Fuseini Zaanyeya with members of his household. Down: Mr. Fuseini Zaanyeya standing in front of his tractor with his household members and some youth in the village, Ghana (Photo: Diama A)

Following Mr. Fuseini Zaanyeya example, many youths have come back to agriculture in Gberimani-Tibogu community. "Many other youths are still carrying stuff in Accra capital city, but I am away ahead of them; they are suffering over there," says Fusseyni who is now his own employer and employs more than 25 workers. Mr. Fuseini Zaanyeya believes that more youth come to the village during cropping season but will migrate back to cities during dry season. He believes that a support in getting an irrigation facility could help settle more of the youth in the village.

Ms. Abibata Yiri (Fig. 8.12) is a member of one nucleus groundnut producers. After the cropping season, she works as a temporary staff of the Heritage Seed 


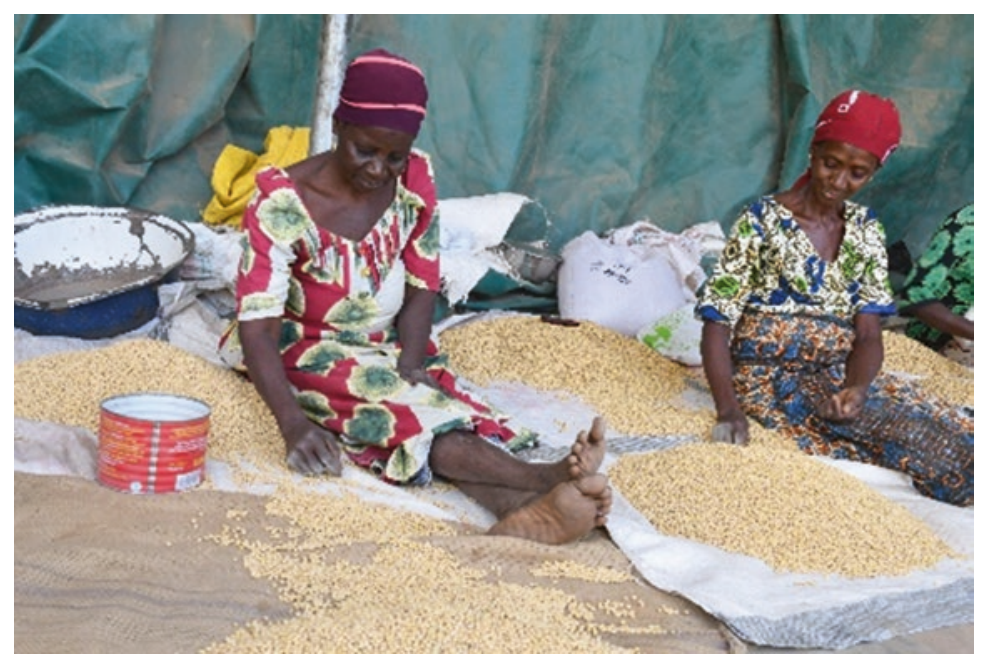

Fig. 8.12. Ms. Abibata Yiri (on right), a member of a Heritage Seed Company nucleus farmers in certified seed production, Ghana (Photo: Diama A)

Company. "I am a groundnut seed out-grower to the company. I produce groundnut and sell it to the company. I get more profit when I sell my produce to the company as compared to the market. It has brought a big change in my life as I can contribute to school fees for my children including providing them with money for their lunch at school."

Open Access This chapter is licensed under the terms of the Creative Commons Attribution 4.0 International License (http://creativecommons.org/licenses/by/4.0/), which permits use, sharing, adaptation, distribution and reproduction in any medium or format, as long as you give appropriate credit to the original author(s) and the source, provide a link to the Creative Commons licence and indicate if changes were made.

The images or other third party material in this chapter are included in the chapter's Creative Commons licence, unless indicated otherwise in a credit line to the material. If material is not included in the chapter's Creative Commons licence and your intended use is not permitted by statutory regulation or exceeds the permitted use, you will need to obtain permission directly from the copyright holder.

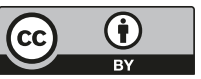

